\footnotetext{
JURNAL CEMERLANG: Pengabdian pada Masyarakat

P-ISSN 2654-4741 / E-ISSN 2655-7894

Vol. 4, No. 1, Desember 2021, 53 - 63

DOI: https://doi.org/10.31540/jpm.v4i1.1391

PENERBIT: LP4MK STKIP PGRI LUBUKLINGGAU
}

\title{
SEMINAR DAN PELATIHAN PENULISAN PROPOSAL PTBK BAGI MAHASISWA BIMBINGAN DAN KONSELING FKIP UNCEN
}

\author{
Habel Saud ${ }^{1}$, Yansen Alberth Reba ${ }^{2}$ \\ ${ }^{12}$ FKIP, Universitas Cendrawasih, Jayapura Papua, Indonesia \\ Email: yansenreba070189@gmail.com
}

\begin{abstract}
ABSTRAK
Kegiatan pengabdian masyarakat ini bertujuan untuk: 1) memiliki pengetahuan dan pemahaman tentang konsep PTK BK, 2) memiliki kompetensi profesional yang mendukung profesi mereka sebagai calon konselor/guru bk yang professional, 3) Memahami secara sistematik dan ilmiah tahap-tahap penelitian tindakan kelas bimbingan dan konseling. Metode yang dipakai dalam kegiatan ini adalah ceramah, diskusi/Tanya jawab, dan pelatihan penulisan proposal penelitian tindakan kelas bimbingan dan konseling. Kegiatan seminar dan pelatihan penulisan proposal penelitian tindakan kelas bimbingan dan konseling melibatkan mahasiswa bimbingan dan konseling semester 4, 6 dan 8 di lingkungan Program Studi Bimbingan dan Konseling FKIP UNCEN. Hasil dari penelitian ini sebagian mahasiswa yang menjawab sangat setuju sebesar 22,86\%, yang jawab setuju sebesar 77,14\%. Dengan demikian dapat disimpulkan bahwa semua Mahasiswa yang mengikuti seminar dan pelatihan penulisan proposal PTK BK dapat mengerti dan memahami dengan baik betapa penting dan bermanfaatnya materi PTK BK bagi mereka sebagai calon guru BK di sekolah.
\end{abstract}

ABSTRACK

This community service activity aims to: 1) find knowledge and understanding of the concept of CAR related to guidance and counseling, 2) define professional competencies that support profession as a prospective counselor/professional counseling teacher, 3) systematically and scientifically understand the stages of classroom action research related to guidance and counselling. The research activities apply the lecture, discussion/question and answer method, and training in writing class action research proposals related to guidance and counseling. Seminars and training for writing class action research proposals related to guidance and counseling involve guidance and counseling students in semesters 4, 6 and 8 of Guidance and Counseling Program of FKIP UNCEN. The results of the study found that students who answered 'strongly agree' were $22.86 \%$ and those who answered 'agree' were $77.14 \%$. In conclusion, all students who attend seminars and training in writing CAR proposals related to guidance and counseling can understand and comprehend well the importance and benefits of $\mathrm{CAR}$ related to $\mathrm{BK}$ material for prospective guidance and counseling teachers in schools.

\section{KEYWORDS ARTICLE HISTORY}

Seminar, Pelatihan, PTBK, Bimbingan dan Konseling

Received 10 November 2021

Revised 29 November 2021

Seminar, Training, PTBK, Guidance and Counseling

Accepted 16 Desember 2021

CORRESPONDENCE Yansen Alberth Reba@yansenreba070189@gmail.com 


\section{JURNAL CEMERLANG: Pengabdian pada Masyarakat P-ISSN 2654-4741 / E-ISSN 2655-7894 \\ Vol. 4, No. 1, Desember 2021, 53 - 63 \\ DOI: https://doi.org/10.31540/jpm.v4i1.1391 \\ PENERBIT: LP4MK STKIP PGRI LUBUKLINGGAU}

\section{PENDAHULUAN}

Keberadaan konselor dalam sistem pendidikan nasional dinyatakan sebagai salah satu kualifikasi pendidik, sejajar dengan kualifikasi guru, dosen, pamong belajar, tutor, widyaiswara, fasilitator, dan instruktur (Anggraini, 2017). Masingmasing kualifikasi pendidik, termasuk konselor, memiliki keunikan konteks tugas dan ekspektasi kinerja (Partadjaja, 2017). Standar kualifikasi akademik dan kompetensi konselor dikembangkan dan dirumuskan atas dasar kerangka pikir yang menegaskan konteks tugas dan ekspektasi kinerja konselor Konteks tugas konselor berada dalam kawasan pelayanan yang bertujuan mengembangkan potensi dan memandirikan konseli dalam pengambilan keputusan dan pilihan untuk mewujudkan kehidupan yang produktif, sejahtera, dan peduli kemaslahatan umum (Ferdialdo, 2018). Pelayanan dimaksud adalah pelayanan bimbingan dan konseling. Konselor adalah pengampu pelayanan ahli bimbingan dan konseling, terutama dalam jalur pendidikan formal dan non formal (Zulvi, 2021).

Bimbingan dan konseling merupakan sebuah pekerjaan professional (Shofaria, 2018). Pendidikan pada jenjang S-1 bimbingan dan konseling pada dasarnya adalah dalam rangka penguatan konsep kelimuan yaitu penguasaan kompetensi akademik sesuai dengan profil lulusan Program Studi Bimbingan dan Konseling FKIP Uncen yaitu Sarjana Bimbingan dan Konseling yang mampu memberikan pelayanan Bimbingan dan Konseling yang sesuai dengan kaidah keilmuan dan perundangan yang berlaku (utamanya : UU Sisdiknas), berwawasan social, multicultural, nilai karakter berbasis lingkungan dan global pada jenjang pendidikan dasar dan menengah, untuk membantu individu mengatasi berbagai masalah yang dihadapi dan membantu mengembangkan potensi yang dimilikinya, dengan memanfaatkan IPTEKS pada bidang Bimbingan dan Konseling (Susanto, 2018).

Salah satu kompetensi yang diharapkan dikuasai oleh mahasiswa adalah kemampuan penguasaan akan penelitian tindakan bimbingan dan konseling secara professional (Pandiangan, 2019). Dengan penguasaan PTBK maka pelayanan 


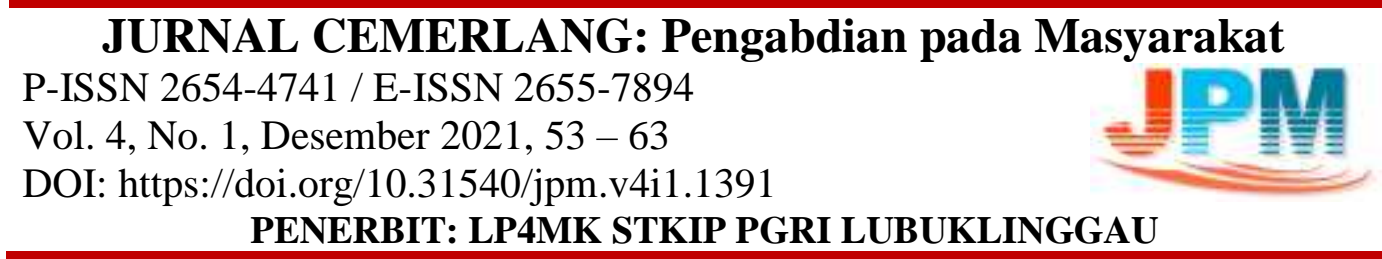

bimbingan dan konseling bisa dilakukan secara professional dalam pengembangan pribadi peserta didik sesuai kebutuhannya masing-masing.

\section{METODE}

Peningkatan kemampuan konseloratau calon guru BK agar mampu menguasai konsep dan praksis penelitian dalam bimbingan dan konseling, yaitu meliputi kompetensi : 1) Memahami berbagai jenis dan metode penelitan, 2) Mampu merancang penelitian tindakan kelas bimbingan dan konseling, 3) Melaksanakan penelitian tindakan kelas bimbingan dan konseling, 4) Memanfaatkan hasil penelitian dalam bimbingan dan konseling dengan mengakses jurnal pendidikan dan bimbingan dan konseling.

Proses rekruitmen peserta (mahasiswa) dalam pelatihan penulisan proposal tindakan kelas bimbingan dan konseling adalah mengundang mahasiswa angkatan 2017, 2018, dan 2019. Adapun metode yang dipakai dalam kegiatan ini adalah ceramah, diskusi/Tanya jawab, dan pelatihan penulisan proposal penelitian tindakan kelas bimbingan dan konseling.

Kegiatan seminar dan pelatihan penulisan proposal penelitian tindakan kelas bimbingan dan konseling melibatkan mahasiswa bimbingan dan konseling semester 4, 6 dan 8 di lingkungan Program Studi Bimbingan dan Konseling FKIP UNCEN. Hal ini dimaksudkan agar para mahasiswa memiliki pengetahuan dan pemahaman tentang konsep dan langkah-langkah penulisan proposal PTK BK.

Evaluasi terhadap kegiatan seminar pelatihan penulisan proposal PTK BK dilakukan dengan cara memberikan pree test, post test dan penugasan penulisan proposal dengan tujuan untuk melihat penguasaan konsep dan langkah-langkah penulisan PTBK.

\section{HASIL dan PEMBAHASAN}

Pelaksanaan kegiatan pengabdian kepada masyarakat yang dilalksanakan bagi para mahasiswa bimbingan dan konseling, dilakukan secara bertatap muka. 


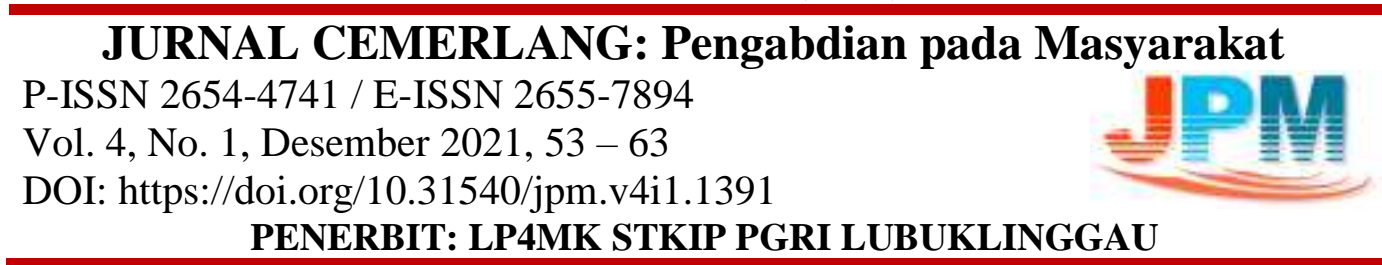

Mahasiswa yang diundang mengikuti kegiatan seminar dan pelatihan penyusunan proposal penelitian tindakan kelas bimbingan dan konseling adalah seluruh mahasiswa dari semester 2 sampai semester 8, namun yang hadir dalam kegiatan tersebut hanya berjumlah 35 orang saja, dan kegiatan ini dilaksanakan pada hari sabtu, 26 Juni 2021.

Kegiatan seminar dan pelatihan penulisan proposal PTK BK dilaksanakan melalui tiga metode/cara, yaitu memberikan ceramah, diskusi dan penyusunan proposal bab 1 sampai bab 3 dan dikordinir atau dibimbing oleh tiga orang sebagai tim, dan proses berjalan selama kurang lebih 3 jam.

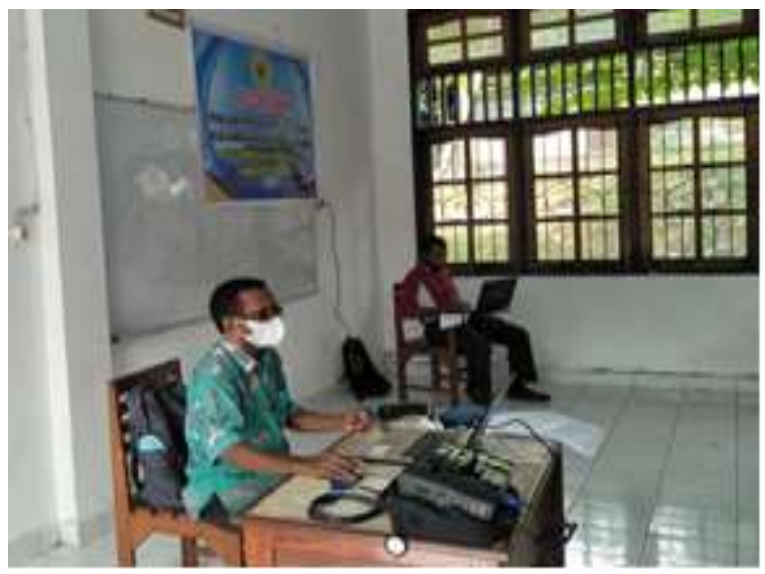

Gambar 1. Dokumentasi PKM pada saat memberikan ceramah tentang PTKBK

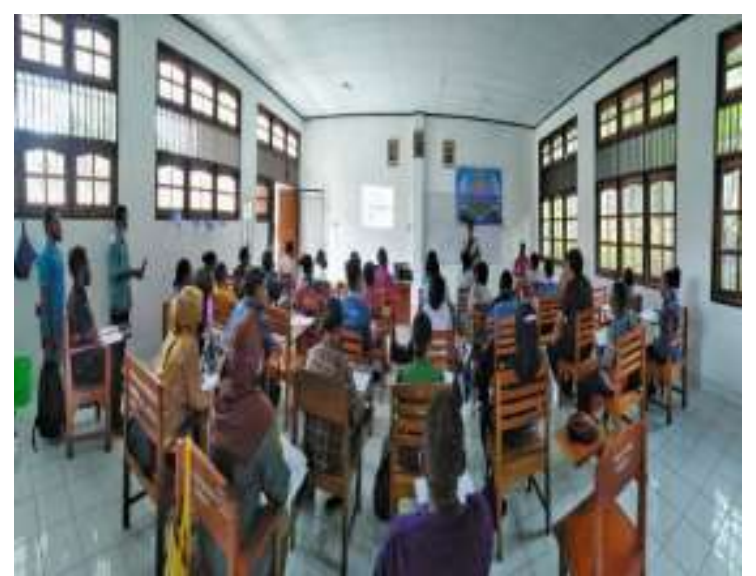

Gambar 2. Dokumentasi pada saat diskusi tentang PTKBK

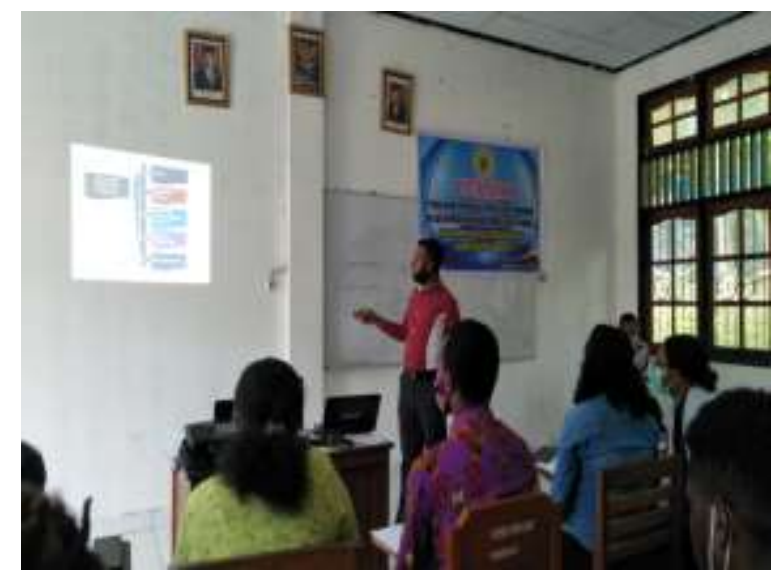

Gambar 3. Dokumentasi PKM pada saat pembimbingan penyusunan proposal PTKBK 


\section{JURNAL CEMERLANG: Pengabdian pada Masyarakat \\ P-ISSN 2654-4741 / E-ISSN 2655-7894 \\ Vol. 4, No. 1, Desember 2021, 53 - 63 \\ DOI: https://doi.org/10.31540/jpm.v4i1.1391 \\ PENERBIT: LP4MK STKIP PGRI LUBUKLINGGAU}

Tabel 1. Hasil Evaluasi Seminar dan Pelatihan PTK BK

\begin{tabular}{|c|l|c|c|c|c|}
\hline No & \multicolumn{2}{|c|}{ Pertanyaan/Pernyataan } & \multicolumn{4}{|c|}{ Kategori } \\
\cline { 2 - 6 } & Jwb 4 & Jwb 3 & Jwb 2 & Jwb 1 \\
\hline 2 & $\begin{array}{l}\text { Saya mengerti dan memahami arti } \\
\text { PTK BK }\end{array}$ & $22,86 \%$ & $74,29 \%$ & $2,86 \%$ & $0 \%$ \\
\hline $\begin{array}{l}\text { Saya Mengerti dan paham tentang } \\
\text { tujuan dilaksanakannya PTK BK di } \\
\text { sekolah }\end{array}$ & $14,29 \%$ & $80 \%$ & $5,71 \%$ & $0 \%$ \\
\hline 3 & $\begin{array}{l}\text { Saya mengerti dan paham manfaat } \\
\text { di laksanakannya PTK BK di } \\
\text { sekolah }\end{array}$ & $20 \%$ & $80 \%$ & $0 \%$ & $0 \%$ \\
\hline 4 & $\begin{array}{l}\text { Saya mengerti dan memahami } \\
\text { langkah-langkah pelaksanaan PTK } \\
\text { BK }\end{array}$ & $14,29 \%$ & $62,86 \%$ & $20 \%$ & $2,85 \%$ \\
\hline 5 & $\begin{array}{l}\text { Setelah mengikuti kegiatan seminar } \\
\text { dan pelatihan ini, saya jadi tahu } \\
\text { cara menulis proposal PTK BK }\end{array}$ & $34,29 \%$ & $51,43 \%$ & $11,42 \%$ & $2,85 \%$ \\
\hline 6 & $\begin{array}{l}\text { Kegiatan seminar dan pelatihan } \\
\text { PTK BK ini sangat bermanfaat bagi } \\
\text { saya sebagai calon guru bk di } \\
\text { sekolah. }\end{array}$ & $77,14 \%$ & $22,86 \%$ & $0 \%$ & $0 \%$ \\
\hline
\end{tabular}

Data table di atas di buat dalam diagram pie masing-masing pernyataan ke 1 sampi pernyataan ke 6 untuk melihat besaran wilayah dengan presentasenya.

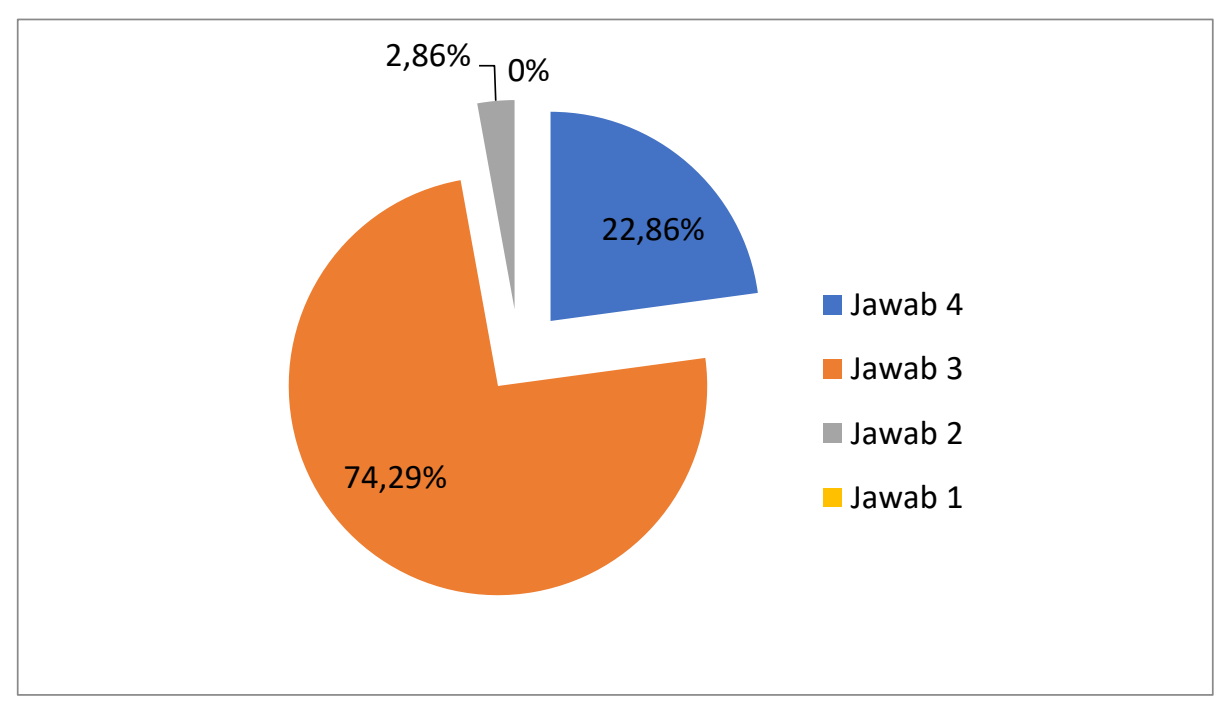

Gambar 4. Mengerti dan Memahami arti PTK BK 


\section{JURNAL CEMERLANG: Pengabdian pada Masyarakat P-ISSN 2654-4741 / E-ISSN 2655-7894 \\ Vol. 4, No. 1, Desember 2021, 53 - 63 \\ DOI: https://doi.org/10.31540/jpm.v4i1.1391 \\ PENERBIT: LP4MK STKIP PGRI LUBUKLINGGAU}

Berdasarkan data table dan gambar diagram pada butier pernyataan satu menunjukan bahwa setelah mengkuti kegiatan seminar dan pelatihan PTK BK, sebagian besar mahasiswa yang menjawab sangat setuju sebesar 22,86\%, yang jawab setuju sebesar (74,29 \%), dan yang menjawab kurang setuju sebesar 2,86\%. Hal ini dapat disimpulkan bahwa sebagaian besar Mahasiswa telah memiliki pengertian dan pemahaman yang baik tentang konsep PTK BK, sedangkan sedikit saja yang belum mengerti dan memahami konsep PTK BK.

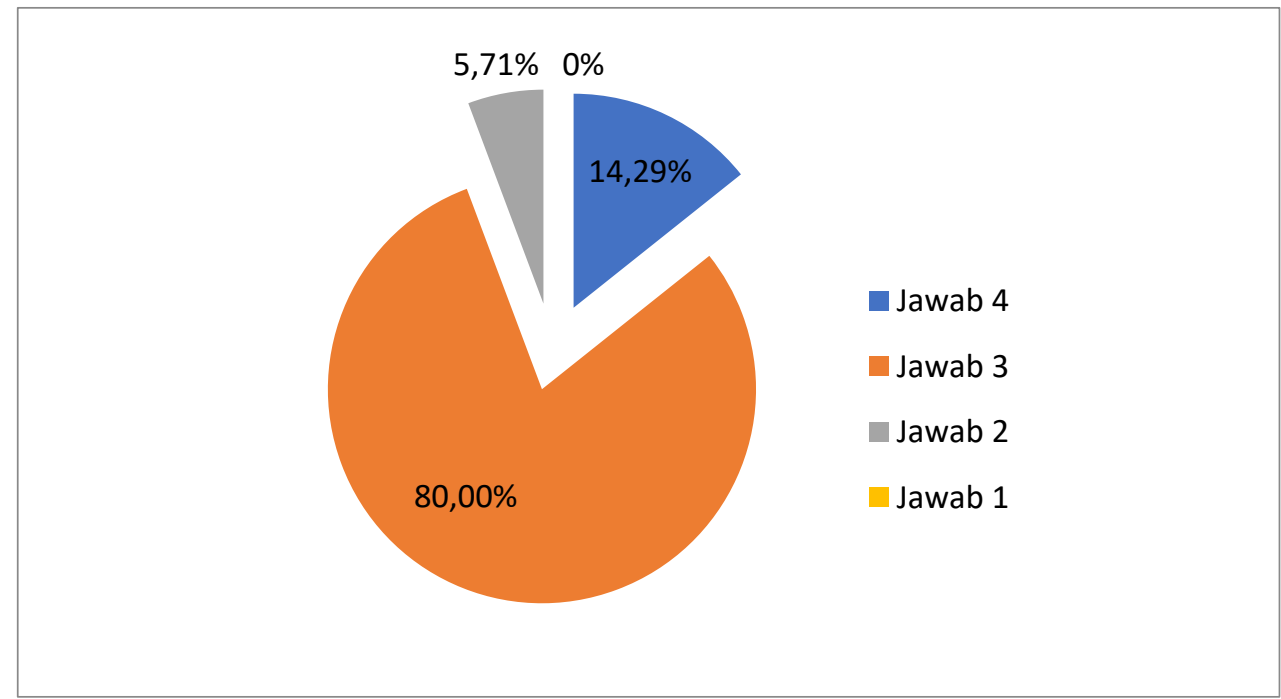

Gambar 5. Mengerti dan Memahami Tujuan Pelaksanaan PTK BK di Sekolah

Berdasarkan data tabel dan gambar diagram pada butier pernyataan dua menunjukan bahwa setelah mengkuti kegiatan seminar dan pelatihan PTK BK, sebagian besar mahasiswa yang menjawab sangat setuju sebesar 14,29\%, yang jawab setuju sebesar (80\%), dan yang menjawab kurang setuju sebesar 5,71\%. Hal ini dapat disimpulkan bahwa sebagaian besar Mahasiswa telah memiliki pengertian dan pemahaman yang baik tentang tujuan pelaksanaan PTK BK di sekolah, sedangkan sedikit saja yang belum mengerti dan memahami tujuan pelaksanaan PTK BK. 


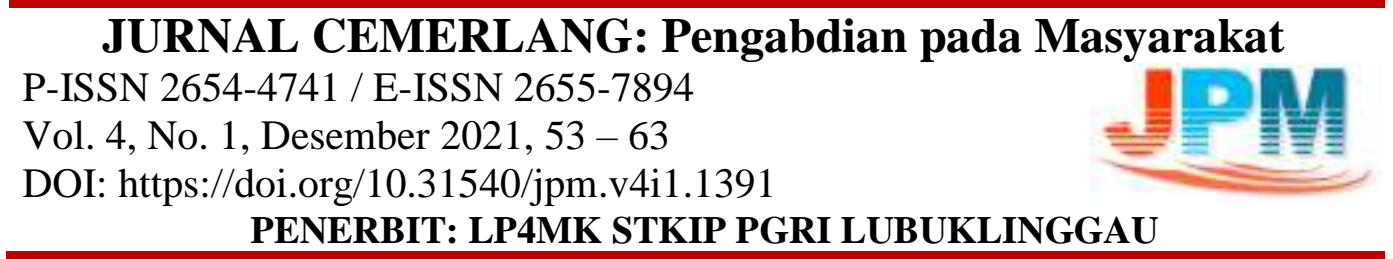

PENERBIT: LP4MK STKIP PGRI LUBUKLINGGAU

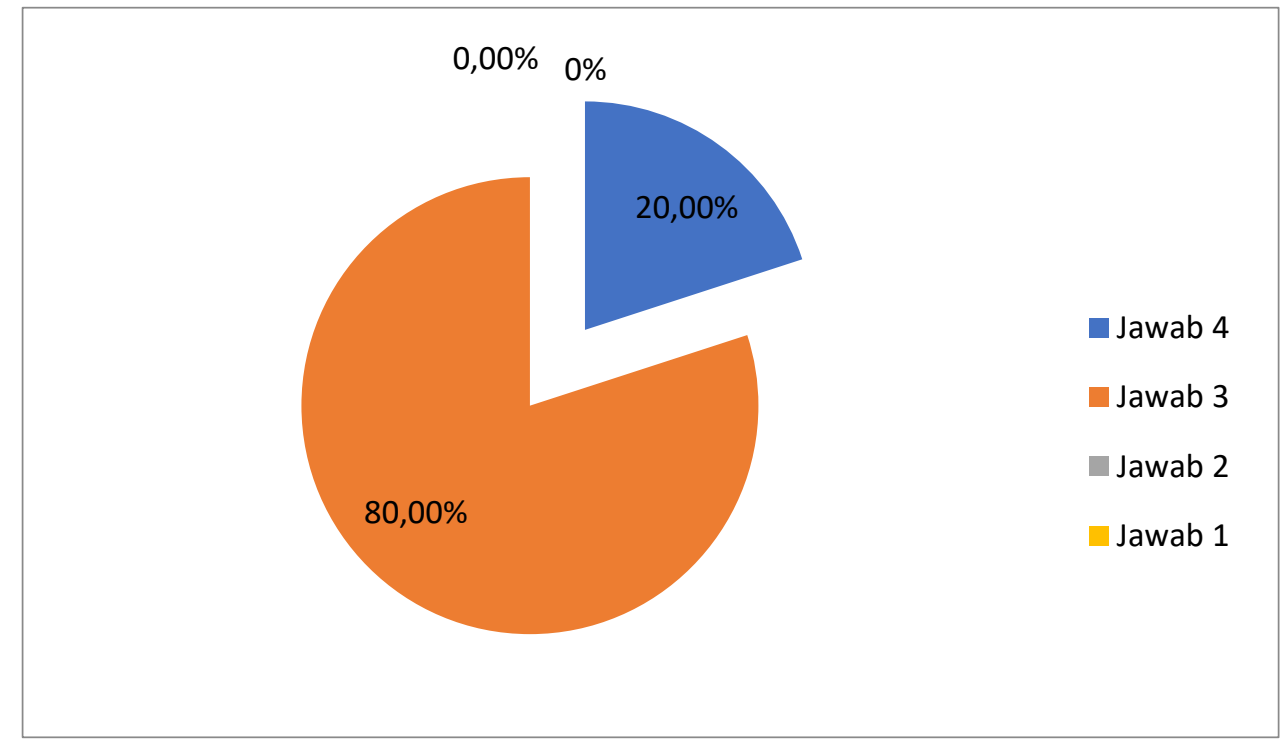

Gambar 6. Mengerti dan Memahami Manfaat Pelaksanaan PTK BK di Sekolah

Berdasarkan data tabel dan gambar diagram pada butir pernyataan tiga menunjukan bahwa setelah mengkuti kegiatan seminar dan pelatihan PTK BK, sebagian besar mahasiswa yang menjawab sangat setuju sebesar 20\%, yang jawab setuju sebesar (80\%). Hal ini dapat disimpulkan bahwa seluruh Mahasiswa telah mengerti dan memahami dengan baik manfaat dilaksanakannya PTK BK di sekolah.

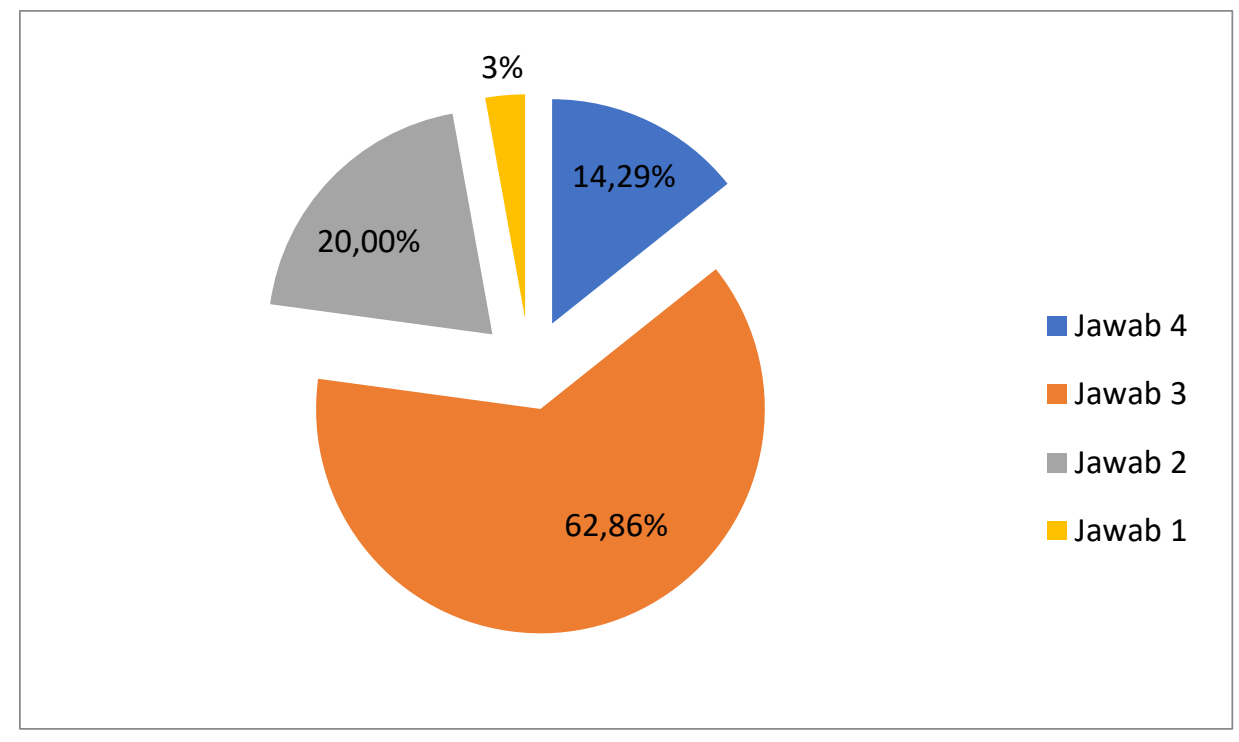

Gambar 7. Mengerti dan Memahami Langkah-langkah Pelaksanaan PTK BK

https://ojs.stkippgri-lubuklinggau.ac.id/index.php/JPM 


\section{JURNAL CEMERLANG: Pengabdian pada Masyarakat P-ISSN 2654-4741 / E-ISSN 2655-7894 \\ Vol. 4, No. 1, Desember 2021, 53 - 63 \\ DOI: https://doi.org/10.31540/jpm.v4i1.1391 \\ PENERBIT: LP4MK STKIP PGRI LUBUKLINGGAU}

Berdasarkan data tabel dan gambar diagram pada butir pernyataan empat menunjukan bahwa setelah mengkuti kegiatan seminar dan pelatihan penulisan proposal PTK BK, sebagian besar mahasiswa yang menjawab sangat setuju sebesar 14,29\%, yang jawab setuju sebesar $62,86 \%$, yang menjawab kurang setuju sebesar $20 \%$, dan yang menjawab tidak setuju sebesar 2,85\%. Dengan demikian dapat disimpulkan bahwa sebagaian besar Mahasiswa dapat mengerti dan memahami dengan baik langkah-langkah pelaksanaan PTK BK di sekolah, sedangkan sedikit atau sebagian kecil mahasiswa yang belum mengerti dan memahami dengan baik langkah-langkah pelaksanaan PTK BK di sekolah.

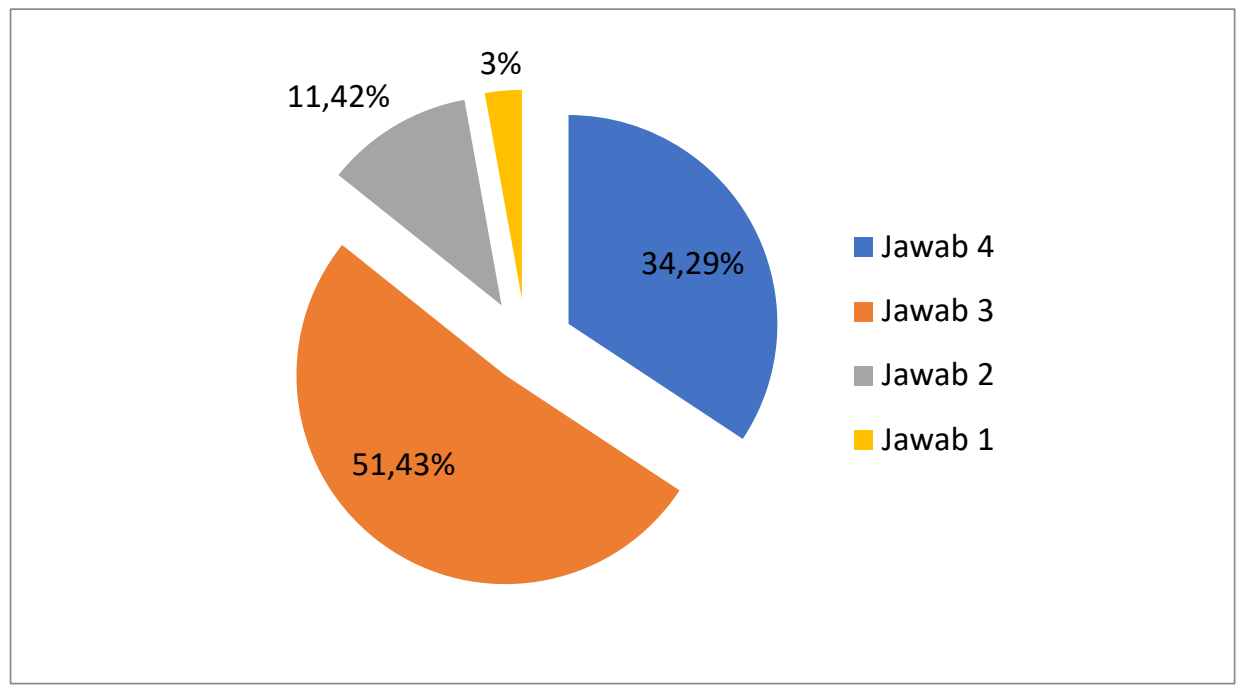

Gambar 8. Mengerti dan Memahami Cara Menulis Proposal PTK BK

Berdasarkan data tabel dan gambar diagram pada butir pernyataan lima menunjukan bahwa setelah mengikuti kegiatan seminar dan pelatihan penulisan proposal PTK BK, sebagian besar mahasiswa yang menjawab sangat setuju sebesar 34,29\%, yang jawab setuju sebesar 51,43\%, yang menjawab kurang setuju sebesar 11,42\%, dan yang menjawab tidak setuju sebesar 2,85\%. Dengan demikian dapat disimpulkan bahwa sebagian besar Mahasiswa dapat mengerti dan memahami dengan baik cara menulis proposal PTK BK dengan baik, sedangkan sedikit atau sebagian kecil mahasiswa yang belum tahu cara menulis proposal PTK BK dengan baik. 


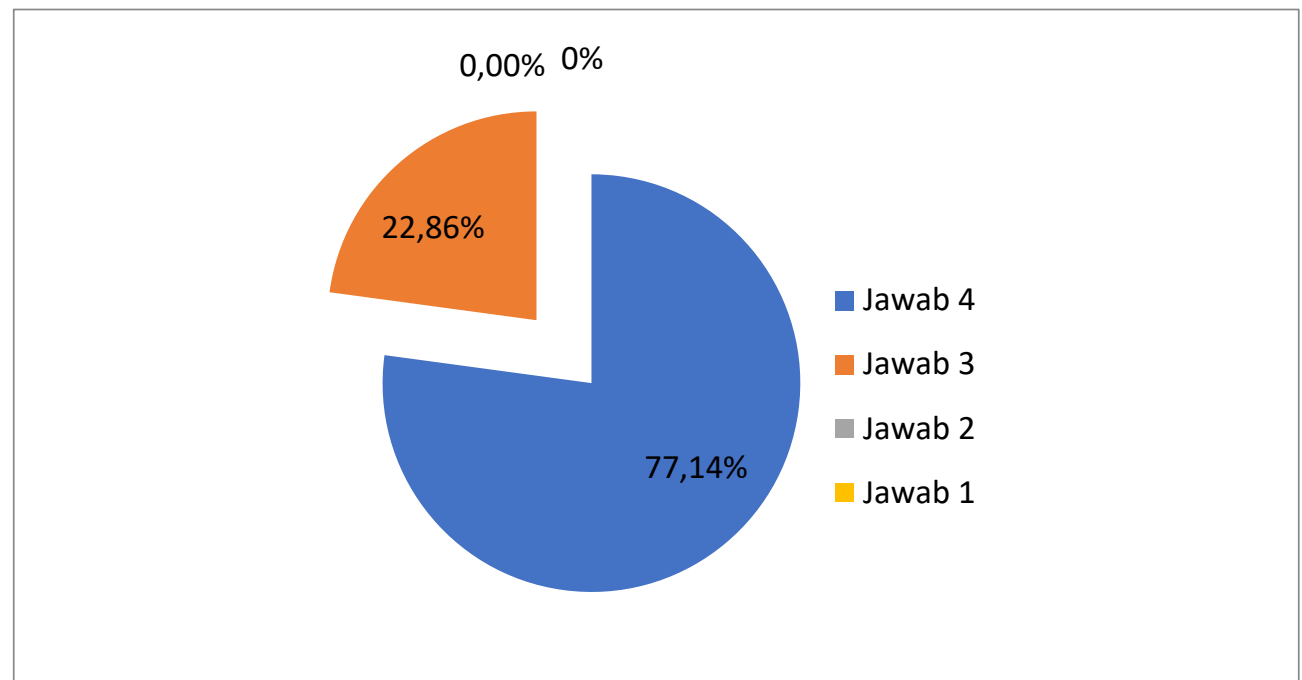

Gambar 9. Kegiatan Seminar dan Pelatihan PTK BK Sangat Bermanfaat Bagi Mahasiswa Sebagai Calon Guru BK di Sekolah

Berdasarkan data tabel dan gambar diagram pada butir pernyataan enam menunjukan bahwa setelah mengkuti kegiatan seminar dan pelatihan penulisan proposal PTK BK, sebagian mahasiswa yang menjawab sangat setuju sebesar $22,86 \%$, yang jawab setuju sebesar 77,14\%. Dengan demikian dapat disimpulkan bahwa semua Mahasiswa yang mengikuti seminar dan pelatihan penulisan proposal PTK BK dapat mengerti dan memahami dengan baik betapa penting dan bermanfaatnya materi PTK BK bagi mereka sebagai calon guru BK di sekolah.

Berdasarkan hasil evaluasi terhadap pengertian dan pemahaman mahasiswa menunjukan bahwa sebagian besar memiliki pemahaman dan pengertian yang baik tentang konsep, tujuan, manfaat serta metode dan langkah-langkah/prosedur penelitian tindakan kelas bimbingan dan konseling (PTK BK).

Mahasiswa sebagai calon guru bk/konselor sekolah dituntut menguasai kompetensi professional, diantaranya mampu menguasai jenis dan metode penelitian penelitian, mampu merancang penelitian bimbingan dan konseling, melaksanakan penelitian bimbingan dan konseling, memanfaatkan hasil penelitian dalam bimbingan dan konseling dengan mengakses jurnal pendidikan dan bimbingan dan konseling (Hikmawati, 2016). Hal ini telah di atur dalam Undangundang Republik Indonesia nomor 20 tahun 2003 mengenai Sistem Pendidikan 


\footnotetext{
JURNAL CEMERLANG: Pengabdian pada Masyarakat

P-ISSN 2654-4741 / E-ISSN 2655-7894

Vol. 4, No. 1, Desember 2021, 53 - 63

DOI: https://doi.org/10.31540/jpm.v4i1.1391

PENERBIT: LP4MK STKIP PGRI LUBUKLINGGAU
}

Nasional pasal 39 ayat 2 yang menjelaskan bahwa pendidik adalah tebaga profesional dengan tugasnya untuk melakukan perencanaan dan pelaksanaan pada proses pembelajaran, melakukan penilaian selama proses pembelajaran, memberikan bimbingan dan melakukan pelatihan serta melakukan penelitian dan pengabdian terhadap masyarakat.

Guru yang memiliki kemampuan dalam menguasai penelitian tindakan kelas dengan baik, maka ia mampu mengembangkan dan meningkatkan kompetensinya untuk mendukung tugas-tugas pelayanan bimbingan dan konseling secara baik (Fitrah, 2018). Karena penelitian tindakan bimbingan dan konseling sebagai upaya reflektif guru untuk terus memperbaiki kinerja. Karena penelitian tindakan memiliki fungsi untuk memperbaiki dan meningkatkan praktek pelayanan konseling bagi siswa di sekolah (Dewi, 2010).

Dengan menguasai PTK BK dapat membantu memberikan manfaat yang besar bagi guru BK/konselor untuk terus mengembangkan diri menjadi lebih professional. Banyak manfaat bisa diraih ketika dilakukan penelitian PTK BK oleh konselor, manfaat tersebut dapat dilihat pada beberapa komponen antara lain inovasi pelayanan, peningkatan profeisonalisme konselor, pengembangan standar layanan kelas dan sekolah (Unesa, 2013).

\section{SIMPULAN}

Sebagian mahasiswa yang menjawab sangat setuju sebesar 22,86\%, yang jawab setuju sebesar 77,14\%. Dengan demikian dapat disimpulkan bahwa semua Mahasiswa yang mengikuti seminar dan pelatihan penulisan proposal PTK BK dapat mengerti dan memahami dengan baik betapa penting dan bermanfaatnya materi PTK BK bagi mereka sebagai calon guru BK di sekolah.

\section{DAFTAR PUSTAKA}

Anggraini, S. (2017). Peran supervisi bk untuk meningkatkan profesionalisme guru Bk. Prosiding Seminar Bimbingan Dan Konseling, 1(1), 332-341. 


\section{JURNAL CEMERLANG: Pengabdian pada Masyarakat}

P-ISSN 2654-4741 / E-ISSN 2655-7894

Vol. 4, No. 1, Desember 2021, 53 - 63

DOI: https://doi.org/10.31540/jpm.v4i1.1391

PENERBIT: LP4MK STKIP PGRI LUBUKLINGGAU

Dewi, R. (2010). Profesionalisasi Guru Melalui Penelitian Tindakan Kelas. Pascasarjana Unimed.

Ferdialdo, K. (2018). Efektifitas Konseling Kelompok Dengan Pendekatan Realitas Dalam Meningkatkan Aktivitas Belajar Peserta Didik Kelas Viii Smp Pgri 6 Bandar Lampung Tahun Ajaran 2017/2018 [PhD Thesis]. UIN Raden Intan Lampung.

Fitrah, M. (2018). Metodologi penelitian: Penelitian kualitatif, tindakan kelas \& studi kasus. CV Jejak (Jejak Publisher).

Hikmawati, F. (2016). Bimbingan dan konseling. Rajawali Press.

Pandiangan, A. P. B. (2019). Penelitian Tindakan Kelas: Sebagai Upaya Peningkatan Kualitas Pembelajaran, Profesionalisme Guru Dan Kompetensi Belajar Siswa. Deepublish.

Partadjaja, T. R. (2017). Pelatihan Penyusunan Rencana Pelayanan Bimbingan Konseling Berbasis Data Alat Ungkap Masalah Kepada Para Guru Bk Di Kecamatan Sukawati Gianyar. WIDYA LAKSANA, 1(2), 94-98.

Shofaria, N. (2018). Ragam Profesionalisme Guru Bimbingan dan Konseling Zaman Now. Seminar Nasional Bimbingan Konseling, 2(1), 33-41.

Susanto, A. (2018). Bimbingan dan konseling di Sekolah: Konsep, teori, dan aplikasinya. Kencana.

Zulvi, N. W. (2021). Pendidikan Konselor Abad 21. IJoCE: Indonesian Journal of Counseling and Education, 2(2), 72-82. 